\title{
Looking north or looking anywhere? Indo-Fijian international relations after the coups of May 2000 and December 2006
}

\author{
Eberhard Weber ${ }^{*}$ (D)
}

*Correspondence:

weber_e@usp.ac.fj

School of Geography, Earth

Science and Environment,

The University of the South

Pacific, Laucala Campus,

Suva, Fiji

\begin{abstract}
Between 1987 and 2006 Fiji experienced four coups in which Governments were overthrown by their military forces or parts of it. After the fourth coup in December 2006 old metropolitan friends such as Australia, New Zealand, the USA and the EU responded with travel sanctions, cancellation of military cooperation and frozen development assistance. When Fiji was politically isolated it fostered secondary political friendships of olden days and established new ones. The paper searches for evidence of Fiji's agency to change the structure of its International Relations (IR) after the coup of 2000. Such relations were first shaped in Prime Minister Qarase's 'Look North' policy, but following the coup of December 2006 Fiji's IR took a new quality once political isolation was overcome and internal power stabilized. The paper concentrates on IndoFijian relations, which, however, are embedded in Fiji's general effort to achieve greater independence from old friends by forcing new international relationships. Of particular interest in this context is, if Fiji's political orientation after 2006 has just been a temporary necessity born out of political isolation or if Fiji's policy of fostering South-South relations will remain a decisive element of the country's foreign policy in the long term. To understand IR in the context of Fiji and India it is essential to look at both countries, their interests and agency. Looking at Fiji alone would leave the question unanswered, why Indian Governments had an interest to cooperate with the country in the Pacific Islands despite hard-core nationalist anti-Indian sentiments and politics pursued in Fiji after the coup of 2000. It also won't be conclusive why India should be interested at all to foster high profile relations with a tiny country like Fiji in a situation when Indian governments were aiming at much higher goals.
\end{abstract}

Keywords: Fiji, India, International relations, Coup 2006, Coup 2000

\section{Background}

Small states, and in particular Small Island Developing States (SIDS) have been subject to academic discourses since quite a while. Briguglio (1995) diagnoses them economic vulnerability while some highlight particular advantages resulting from unique economic structures and processes (Bertram and Watters 1986; Poirine 1998). In Political Science small states have been subject of reflection since long (Baker Fox 1959; Hambro 1936, 1943; Herre 1937; Keohane 1969; Rappard 1934; Wilcox 1967; Wolfers 1945). Early publications often concentrate on small states in the developed world. With

(c) The Author(s) 2017. This article is distributed under the terms of the Creative Commons Attribution 4.0 International License (http://creativecommons.org/licenses/by/4.0/), which permits unrestricted use, distribution, and reproduction in any medium, provided you give appropriate credit to the original author(s) and the source, provide a link to the Creative Commons license, and indicate if changes were made. 
de-colonization in Asia, Africa and finally the Pacific Islands region developing states more recently became subject of political discourses (Skagestad 1974; Vellut 1967). Questions around alignment or non-alignment during the cold war were discussed with regards to small states (Keohane 1971; Liska 1968; Rothstein 1966, 1968). Political properties of SIDS draw the attention of academia from the early 1980s (Clarke and Payne (eds.) 1987; Dommen and Hein (eds) 1985; Sutton and Payne 1993). The SIDS received official recognition as a distinct group of developing countries at the United Nations Conference on Environment and Development (UNCED) in June 1992 (Grote 2010; Karlsson-Vinkhuyzen 2012). Since then a substantial part of the literature on SIDS reflects on political aspects of environmental and climate change and the increasing role SIDS play in international discourses and events that relate to these challenges (Kelman 2006).

Fiji is a SIDS. Although the economically most advanced and second most populated country in the Pacific Islands region it is a Lilliput compared to many of the powers it has intensified political relationships in the past 15 years, such as China and India. Relations with the latter stands in the centre of this paper.

\section{Methods}

The paper analyses Indo-Fijian international relations (IR) as they unfold after the year 2000. A number of critical events have been analysed to find evidence for Fijis agency in IR. Events that show how a small country, endangered to become internationally isolated, tried to actively change the international structure in which its IR are embedded. As the result of colonial divide and rule policies and the coups of 1987 Indo-Fijian relations were often retarded. Since the early years of the 21st century, however, Fiji's governments found a more harmonious relationship with India. To explain such sudden shift in Indo-Fijian relations an analysis of the interests and challenges of Fiji governments needs to be combined with an analyse of changes in India's foreign policy aiming to improve its relationship with Fiji and start engaging with other Pacific Islands Countries (PICs).

The ontological question in this regards is about the nature of the international system a small country like Fiji is embedded. Do we have a structure which determines Fiji's IR, or is there creative leeway for a tiny country to change its structures strengthening Fiji's perceived interests and aspirations? The paper thus searches for evidence of Fiji's agency arising from opportunities and constraints to change the structure of its international system for its own perceived interests. In case such agency is attested, further questions need to deal with the factors that explain why the old system is considered unwanted. In addition to the questions, if agency exists and what particular actions to change the existing structure were pursued and why they were pursued a fourth consideration is seen as important: how is agency applied? This refers to the mechanisms of social construction of IR. In the present paper such discourse analysis presenting a deconstruction of Fiji's intentions and efforts in forging new IR cannot be accomplished. This important endeavour must be reserved to another paper, which then goes deeper into the mechanisms of the social construction of IR.

To understand relationships between Fiji and India it is essential to look at both countries, their interests and agency. Looking at Fiji alone leaves the question unanswered, 
why Indian Governments had an interest to closely cooperate with Fiji. After the coup of 2000 hard-core nationalist anti-Indian sentiments and policies were pursued by the Qarase Government. After the coup of 2006 Fiji was ruled by an undemocratic military-backed government endangered to become an international pariah. Both would have been relevant reasons to freeze Fiji off when it approached India, the world's biggest democracy. It also won't be conclusive why India should be interested at all to foster political relations with a tiny country like Fiji in a situation when Indian governments were in the process to construct a high profile politically. To deal with a country that was internationally shunned and sometimes even disdained could easily turn contra-productive.

To explain the convergence between the two countries which started soon after the coup of 2000 under Prime Minister Qarase's government (and not after the coup of 2006) various interests in both countries need to be analysed and embedded into the changing global political environment. In this context it needs to be elaborated when exactly the turning point happened that evoked Fiji's agency to change the structure its IR are embedded. Arguing from a macro, international system perspective many political scientists would take the end of the Cold War as starting point. This major turning point in history is surely relevant, but more for India's changing aspirations.

\section{The construction of international relations}

Four mega-events dominated IR in the twentieth century, World Wars I and II, the Cold War and the end of it, ending also an alleged bi-polar global power system. They first gave birth to IR as an academic discipline, dealing with major issues around war and peace, security forces and their structural changes, decolonization, alliances and alignments, global multinational institutions such as the League of Nations and the United Nations, and diplomacy. The twentyfirst century added new issues, without most of the old ones becoming obsolete: terrorism, and the war against it, politicized religion, globalization and global environmental change including climate change. Different eras produced various, often contradicting theories, approaches and paradigms of how to conceptualize IR.

Realist paradigms were first nourished by events of the 1930s, when political extremism exposing "fundamental truths of human nature" (Behnke 2001: 124) led to World War II (Morgenthau 1948). Waltz (1979) drafted his neorealist paradigm before the background of the Cold War, anti-communist sentiments and fundamental angst of a nuclear apocalypse. He argued that the lack of a generally accepted global orderer leaves the global political system in a state of anarchy enhancing the dangers of wars and violent international conflicts. The Balance of (military) Power helped to avoid Armageddon creating not peace, but an absence of war, more precisely: an absence of direct military confrontation between the superpowers.

While some aspects in IR that effect political relations between Fiji and India can be explained through such neorealist paradigm, much remains, which doesn't fit to this grand theory, especially events in the twentyfirst century. At times, they even contradict what neorealist theories claim how IR are forged. These contradictions ask for alternative explanations: a constructivist paradigm looking at the agency of states, their interests, their identity, their opportunities and constraints rather than assuming an 
overarching quasi-deterministic structure of an international system in which IR are moulded (Weber 2010).

States are actors in such system, whose major motivation is to survive/prevail against other states. All of them are driven by inherent systemic constraints, which constantly result that they try to achieve own advantages at the expense of other states.

Constructivists see human agency produce their world. This has crucial importance also for IR. States act under conditions which have evolved historically. They are embedded into institutions, values and rules that create particular opportunities to act and at the same time produce constraints restricting agency.

Approaches of social construction in IR are critical supplements rather than denial of neorealist theories highlighting immaterial aspects of IR, such as identities, values, and cultural constitutions for IR (Copeland 2000). Wendt (1992) argues that state action is not determined by structures, but states interact and learn and are thus able to use their reflexivity to cooperate with each other or to act in their own interest at the expense of other states.

Wendt $(1987,1999)$ agrees with many of the main assumptions of neorealist paradigms: like neorealists he assumes an anarchistic international system, in which states are the main actors, but he adds a subjectivist ontology. "States are states: politics only starts when they begin to negotiate their outward social identities" (Behnke 2001: 122). International politics, like any other politics, is a human activity. IR are thus effected by human reflexivity or "social learning" (Drulák 2006: 139), meaning the response to structural conditions with the aim to change structures for gains and advantages. Such reflexivity is the foundation of Giddens' structuration approach, who perceives modernity as "a reflexive system which continually evaluates and remakes social practices" (Drulák 2006: 150). Wendt (1987) introduced structuration to IR taking structure as well human agency seriously. Such approach stands in contrast to behaviourist rational choice.

Another aspect important for the paper is whether-as Waltz (1979) suggests-international compulsion to act in an anarchistic international system does not relate to internal structures, affairs and politics of individual states, but follow quasi-deterministic mechanisms. He claims that IR depend entirely on the power relationship between states; their internal properties are unimportant (Wendt 1999). List (2008)-in contrast-highlights the importance of the mutual interdependence between internal and external factors. State never means an abstract actor or an institutional expression of an abstract national interest to survive, but the outcome of internal structures (Teschke 2003). To elaborate on this idea the formation of IR would include societal structures and cleavages resulting from identities, rules and norms shaped by class formations, ethnicity, gender, and other factors. Adler (2013: 113) emphasizes that social construction approaches deal with "the social construction of knowledge and the construction of social reality [...]. Unlike positivism and materialism, which take the world as it is, constructivism sees the world as a project under construction, as becoming rather than being". With regards to IR this means that "Anarchy is what States make of it", the title of Wendt's (1992) major monography in this discourse. IR thus become the result of reflexive processes rather than structural determinism creating "a" and not "the" "World of Our Making" (Onuf 1989) in the process. Constructivism in IR-more than anything else-is about change (Friedman and Starr 1997). "Constructivist scholarship locates 
different sources of change, but in particular agency, process, structures, and practices, all of which are usually interrelated" (Adler 2013: 123). From a constructivist perspective a state is an actor, who does not act according to objective necessities (this would be the assumption of a neorealist approach), but defines agenda and goals of action, selects appropriate strategies according to relevant internal as well external factors (Haftendorn 1990). IR_-as a result_can become the continuation of internal affairs/domestic politics with different means.

Constructivism negates that the analysis of structure alone can provide meaningful insights in the nature of IR. It is equally important to consider agents and their agency, their opportunities and constraints. Constructivists acknowledge the importance of structures. "Where neorealist and constructivist structuralism really differ, however, is in their assumptions about what structure is made of. Neorealists think it is made only of a distribution of material capabilities, whereas constructivists think it is also made of social relationships" (Wendt 1995: 73).

In addition to constructivism a postcolonial perspective provides the conceptual background for the paper. Postcolonialism "draws attention to the extent to which today's world remains affected by colonial relations" (Zehfuss 2013: 157). With this importance is given to the fact that societal conditions are mediated historically. Structures established in the past, however, are not cast in stone, but can be altered by human agency. In the case of Fiji the past has been a colonial past, which resulted in concrete societal circumstances, which were prone to conflicts in the postcolonial era.

\section{A short history of the Indian diaspora in Fiji}

India has considerable diaspora in many parts of the world. Many were created when India was the crown jewel of the British colonial empire. Indians were exported as cheap labour to British colonies in Africa, the Caribbean Islands, the Indian Ocean and also the Pacific Islands. By early 2015 more than 28 million people with Indian ancestry were living outside India (Ministry of Overseas Indian Affairs 2015). Some 16 million of them had been born in India making Indians the world's biggest diaspora. By 2016 there were some 274,000 people of India decent living in Fiji, about 31.5\% of the country's population (Fiji Bureau of Statistics 2017). Only Mauritius (71\%), Trinidad and Tobago (41\%), and Guyana (40\%) had higher shares of people with Indian ancestry among their populations (Indian Ministry of External Affairs 2016).

Indian diaspora in Fiji started in 1879 when the first Indians arrived in the colony to work in European plantations. In other colonies, at other times plantation economies were inseparably linked to slave work. Since the 1830s slave trade had been abolished in British colonies. Other 'solutions' became necessary to recruit cheap labour for Pacific plantations. Labour recruitment from within the Pacific islands found its natural limitation in the small populations of the islands, often decimated by diseases introduced by Europeans, internal warfare and harsh recruitment practices (Archer 2010; Igler 2015; Lambert 1934; Rivers 1922; Stevens 1950).

On October 10, 1874 Fiji became a British Colony. European immigration escalated. The main question was who should do the hard work in the expanding sugar cane plantations. In May 1879 the first 463 indentured labourers from India arrived in Fiji. Until the end of 1916 more than 60,000 indentured labourers were brought to Fiji (Lal 2004). 
The majority were men aged 20-40 years. Most of them came from poor, agricultural labourer backgrounds. They saw Fiji as a place to escape exploitation and suppression suffered in India. Once in the country they soon realized that they came out of the frying pan right into the fire. Hard work and extreme living conditions awaited them. Violence like robbery, murder and suicide was widely spread in the working lines of the Indians (Naidu 1980).

Indentured labourers committed themselves to work for 5 years in Fiji, most of them in the plantations of the Colonial Sugar Refinery (CSR) from Queensland, Australia. After that they could return to India on their own expense or sign a contract for another 5 years. With the completion of a second contract they earned an entitlement for a free passage to India, or they could stay in Fiji. Not even half of those who came as indentured labourers to Fiji returned to India. Those who stayed back added a new component to Fiji's demographic structure.

In 1916 the last indentured labourers from India arrived in Fiji. Strong objections from British and Indian politicians (including M.K. Gandhi) and welfare organizations brought an end to a recruitment system that was described as contract slavery (Rodriguez 2011). The last labour contracts expired in the early 1920s. With the end of indentured labour recruitment the interest of the CSR to produce sugar cane vanished. When new, cheap recruits no longer arrived the CSR discontinued cane production and concentrate on processing and marketing sugar. The plantations of the CSR were subdivided into plots of 4-5 hectares in size and offered to former plantation workers as leases (Ellis 1988; Moynagh 1978).

Fiji achieved its independence in 1970 at the height of the Cold War. No fight for independence preceded the end of British rule, no serious conflict with the colonial power. The close and cordial relationship between indigenous Fijian elites and the colonial power continued unabated after independence. Fiji's political orientation strongly supported the capitalist First World.

\section{Ethnic conflicts and insecurity in Fiji}

Fiji's political development has been greatly influenced by its colonial past and the Cold War creating rather unique structures, processes and events, which hardly fit into grand theories of IR. Since Fiji became independent in 1970 it experienced four coup d'états carried out by its military (May 1987, Sept. 1987, Dec. 2006) or parts of it (May 2000) (Fraenkel et al. 2009). These coups had also severe repercussions on Fiji's IR. The coups were usually interpreted as conflicts between Fijis two major ethnic groups, the indigenous population (iTaukei) and Fijians of Indian descent. Although this ethnic explanation of political instability found much favour and flavour among political commentators reality has been more complex. While ethnicity contributed much to political instability in Fiji the existence of additional cleavages based on class, kinship and centre-periphery dichotomy created a multi-layered picture. The coups also related to conflicts within the iTaukei society, between chiefs and commoners, between the three confederacies of Burebasaga, Kubuna, and Tovata. The conflicts were (and still are) about loss of political and economic power in the process of modernization experienced by traditional chiefs of tribal confederacies. Conflicts were also caused by the marginalization of indigenous people, often living in the periphery, demanding their share of the development process 
(Weber 2007). The coups happened before a complex class system. In colonial times the establishment of a multi-ethnic class system had been suppressed by a sophisticated divide and rule policy of the colonial masters preventing the creation of an inter-ethnic labour class consciousness. In this connection one has to keep in mind that the first three coups of the country were against Governments led by the Fiji Labour Party.

Finally external actors such as Australia, New Zealand, the USA and the European Union have added another layer to the conflicts. Pacific islands were nuclear testing grounds of the USA, France and Great Britain as well as a strategic region for the US Pacific Fleet. Although three of the four coups were before 9/11 the USA as well as Australia perceived political instability in the Pacific Island region as a potential breeding ground for international terrorism and a threat to their national security. Discourses that referred to weak or failing states in Africa were transferred to Pacific Islands' situations. The danger of an Africanization of the Pacific became a political discourse, mainly initiated by Australian political scientists (Reilly 2000; critical to it see: Fraenkel 2004). In popular science Robert Kaplan had painted an apocalyptic doomsday picture of a Coming Anarchy in Africa resulting from the decline in power and control of modern nation states in favour of tribal power and territories (Kaplan 1994). Part of the discourse was the reflection on a changing character of war. With the end of the Cold War there had been considerable geo-political dislocations which also changed the character of wars. Classical wars between states had become more and more historically obsolescent models which were replaced by "New Wars" (Kaldor 1999). These and other forms of political violence such as ethnic cleansing and grave human rights violations could only insufficiently explained through a (neo)realist IR paradigm. At least at first sight the causes of such new wars lie often in nationalist, ethnic and/or religious tensions or internal instabilities of failed or rogue states (Weber 2007) rather than a particular international political system. Although scope and degree of violence in Fiji (and elsewhere in the Pacific Islands) were rarely comparable to situations in African states social scientists (and politicians) expressed worries about the danger of territories being beyond the reach and control of state institutions and state power.

\section{Metropolitan powers' interests in Pacific Islands}

The Pacific Ocean had been a major theatre for the USA in World War II. The Japanese attack on Pearl Harbour in December 1941 not only led to the USA's entry into the war, it also provided evidence for the perception of the international system in which human nature, the lack of an ordered international system and preponderance of anarchy led to war and global catastrophe.

During the Cold War the Pacific Ocean became heavily militarized. Japan, joining the capitalist First World, became a major location of US military installations, similar to the Philippines, the Marshall Islands and South Korea. The Soviet Union (USSR), major opponent of the USA in the Cold War and the People's Republic of China (PRC) have considerable coastlines to the Pacific Ocean. Especially the latter has shown hegemonic ambition in the region. Two major wars of the Cold War, the Korean War (1950-1953) and the Vietnam War (1955-1975) were fought in the Pacific Ocean. Western nuclear testing grounds in the Marshall Islands (USA), French Polynesia (France), and Kiribati (Kirtimati Island, UK; USA) as well as ballistic missile testing ranges were major 
components of the Cold War contributing to the Balance of Power through the threat of mutual destruction (Maclellan 2005). The US Pacific Fleet has been the largest military unit of the USA. Besides in Hawai'i and the unincorporated territory of Guam there are naval bases in independent countries such as Japan, the Philippines, and South Korea, all close to the territories of the PRC and the USSR. Well into the 1980s the USA assigned considerable effort to maintain military dominance in the Pacific Islands region, opposing efforts by PICs, Australia and New Zealand to declare the Pacific Ocean a Nuclear Free Zone (Maclellan 2005; Power 1986).

With the end of the Cold War the importance the USA assigned to the Pacific Islands region has been declining. In the 1990s the USA closed its embassies in the Solomon Islands and Samoa and USAID offices in Fiji and PNG. After the end of the Cold War the US Navy has been downsized considerably. In 1989, the year of the fall of the Berlin Wall, the US Navy operated 592 ships; by the end of September 2016 the number had gone down to 275, which was the lowest number of ships operated by the US Navy since 1916. Although US Navy presence is still strongest in the Pacific Ocean with the 3rd and 7th Fleet, the latter sharing also responsibilities in the Indian Ocean considerable reductions in the numbers of ships, personnel and instalments have also taken place here. All naval bases in the Philippines had been shut down by the end of 1992 (McVadon 2007), although in 2016 the US administration under President Obama signed an agreement with the Government of the Philippines to open five new bases that will support deployments near the South China Sea. In the twentyfirst century US interest in the region have been concentrating on US unincorporated territories (American Samoa, Guam, Northern Marianas) and the three Compact of Free Association (COFA) States, Federated States on Micronesia, Marshall Islands and Palau (Serrano 2014). The US Army base on Kwajalein Atoll (USAKA) in the Marshall Islands has been downsized as well as activities and staff of the Ronald Reagan Ballistic Missile Defense Test Site (RTS) on the same atoll (O'rourke et al. 2012). Great Britain's withdrawal from the Pacific Island region is even more complete (Zhang 2007). Australia has taken over as regional power assuming many of the roles the USA had earlier. The decline of US engagement, which happened particularly under George W. Bush's Presidency 2001-2009, was partly revised by President Obama's administration. In October 2010 the then U.S. Secretary of State Hillary Clinton re-confirmed US strong commitment to the Pacific region in a widely noticed speech at the East-West Center on Hawaii (https://www.youtube.com/ watch?v=wrgjRQ648zg).

\section{India's response to the coups of 1987, 2000, and 2006}

Official Indian political representation in Fijis capital Suva was established in 1948, a year after India's independence. A High Commission and cultural centre highlights the importance the Indian state gave to a territory which at this time was still a British colony. In 1981 Prime Minister Indira Gandhi visited the island nation expressing interest in the well-being and welfare of those of Indian ancestry. After the coups of 1987, and then again in 2000 a rather non-political attitude dominated the Indo-Fijian relationship. Each time the Indian Governments trusted much in the ability of the Commonwealth to deal with the crises rather than to take own political initiatives. 
Fiji was expelled from the Commonwealth immediately after the coup of May 1987, which ended a 1 month rule of a coalition government led by the Fiji Labour Party, the political home of the (agricultural) working class of Fijians with Indian ancestry. The Rajiv Gandhi Government reacted much weaker than the Indian and Indo-Fijian public had expected: no sanctions or diplomatic protests such as ordering India's ambassador home when violence targeted against Indo-Fijians erupted in Fiji. Rajiv Gandhi was too much engaged with his own challenges, especially those in Sri Lanka. Gandhi tried to use the Commonwealth and trusted in vain that it intervened politically restoring people's electoral verdict of April 1987.

In May 2000 former CEO of the Fiji Hardwood Corporation, George Speight, and heavy armed soldiers of an anti-terrorist section of the Republic of Fiji Military Forces (RFMF) stormed Fiji's Parliament and took most of the cabinet hostage for almost 60 days. Indian Prime Minister Vajpayee expressed deep concern about the safety of the hostages. Like in 1987 political protests and initiatives were restricted. Neither did the Indian Government lobby internationally for the restoration of the ousted government, nor did it announce or implement any sanctions, which were demanded by many in Indian as well as in Fiji. Disempowered Prime Minister Chaudhry was disappointed by the politically weak response of the Indian government stressing that "we want the Constitution reinstated .... New Delhi must work to achieve the objective of restoration of democracy and protection of political and civil rights of the people of Indian origin; government policies must be in tune with the national mood" (The Hindustan Times 19.08. 2000). Pande (2011: 133) argues that "with no economic or political clout in the region, India had little space to manoeuvre and to exert any influence on the prevailing situation". A similar position was taken by Thakur (1985), who felt already before the first coup that India could do much more for their diaspora in the Pacific, if greater economic and political connectedness would exist.

After the coup of 2000 the exodus of Fijian citizens of Indian ancestry to Australia, New Zealand, the USA and Canada continued, which had started in 1987. In the 1970s more than half of Fiji's population was of Indian ancestry. Between the first coup in May 1987 and the third in May 2000 some 120,000 people left the country for good, most of them citizens of Indian ancestry (Weber 2014). They felt intimidated and endangered by political violence and discrimination.

The coups of 1987 and 2000 had distinct ethnic backgrounds although the complex ethnicity in Fiji was only a part of the conflicts. The coup of 2006, however, lacked such ethnic element almost entirely. To the contrary political intervention of the RFMF happened to safeguard Fiji's multi-ethnic society against a democratically elected government, which had radical nationalist features disadvantaging Fijians of Indian decent. The Congress-led Government under Prime Minister Manmohan Singh pledged support to the Fijian Government disregarding its formal status resulting from the coup in 2006.

\section{From mere necessity to great success}

After the 2006 coup old traditional international relations were disrupted. Old friends such as Australia, New Zealand, the USA and the EU responded immediately with travel sanctions, cancellation of military cooperation and frozen development assistance. To overcome international isolation Fiji formed new alliances or intensifies old, secondary 
ones. New relations were taken up with Cuba, Indonesia, Kazakhstan, Russia, South Africa, Venezuela, and others. The intensification of relations with China stood out, but also Fijis further harmonization with India has been of great importance.

Immediately after the coup of 2006 the need of political diversification became a question of political survival for Fiji. Once this was assured, however, it also became a symbol of Fiji's position in the Global South. It was not that Fiji's military-backed Government had to find new partners, many of them were already there, but their role, their importance, and the purpose why partnerships were intensified changed considerably. From grave necessity to overcome political isolation Fiji soon demonstrate to the world and its own citizens that a small PIC can meaningfully contribute to world politics by grasping 'new opportunities' concentrating on South-South cooperation (Crocombe 2007). Fiji opened Embassies in Indonesia, South Africa (the first in Africa) and Ethiopia, in Brazil (the first in South America). Alone in 2010 Fiji took up diplomatic relations with 37 states. In 2011 the country held diplomatic relations to 114 states (Bainimarama 2011). In this year Fiji joined the Non-Aligned Movement (NAM). Fijis standing in the developing world was impressively displayed in early 2012 when Prime Minister Bainimarama became chair of the International Sugar Council (ISC) for a year. During 2013-in times of military governance-Fiji took chair of the Group of 77 plus China showing the country's great support from 134 developing countries that are members of this most important political institution of developing countries. So far Fiji's greatest decorations on international stage came after the elections of 2014. In September 2016 Ambassador Peter Thomson opened the 71st session of the United Nations General Assembly as its President. In November 2016 Fiji was selected by the United Nations Framework Convention on Climate Change (UNFCCC) to organize the 23rd meeting of the Conference of Parties (COP23). As the small country is not able to accommodate some 20,000 people, who are expected to come for the event, the meeting will be in Bonn, Germany in late 2017. It will be the very first time that a SIDS organizes a COP of the UNFCCC. Already in November 2015 Fiji was leading the Pacific Islands delegation at the COP21 in Paris bringing SIDS concerns to the negotiations on climate change. A few months before COP23, in June 2017, Fiji will be co-hosting the United Nations Oceans Conference in New York (Fiji Times 24.11.2016).

\section{The elections of September 2014: and now?}

Fiji had been without elected government for almost 8 years; it returned to democratic governance through the elections of September 2014. Major actors who had staged a coup almost 8 years earlier were confirmed in power through a landslide victory. Already before the 2014 elections there was re-approachment with old friends. In February 2014 Australian Foreign Minister Bishop visited Fiji as part of the Pacific Islands Forum's Ministerial Contact Group. During her visit she had a separate meeting with Prime Minister Bainimarama. Within 6 weeks after the new old government took office Foreign Minister Bishop returned to Fiji on a state visit. Australia did not want to lose any time to restore the political structure that existed before 2007.

Politicians from New Zealand, Europe and the Middle East followed not much later. The new friends from the Global South did not wait either: India's Prime Minister Narendra Modi started a 2 days state visit on November 19, receiving a fantastic reception 
through India's diaspora in Fiji, when thousands of Fijians of Indian ancestry met Prime Minister Modi in a public reception in Suva's Albert Park; a Prime Minister to touch, a Prime Minister for 'selfy sessions'. Modi had not yet left the country when Chinese President Xi Jinping arrived for a 3 days state visit marking it the first time a Chinese President visited any Pacific Island country. In both events IR became public relation events, events to demonstrate international success stories to Fijian citizens, in particular to those of ethnic Indian and Chinese backgrounds.

\section{'Look North" or 'Look anywhere'?}

India is not the only Asian power that has intensified relations with PICs in the recent past. Many see increasing Asian engagement with PICs particularly reflected in Chinese agency. The major narrative claims an expansionist behaviour of the PRC, its effort to convert economic into political power and to take over from the USA and Australia as regional power in the Pacific Islands region (Henderson et al. 2003).

Such narrative simplifies several aspects: Fiji's 'Look North' policy, i.e. the country's efforts to find new partners in Asia started under the Qarase Government. When commentators e.g. highlight a sharp increase of development assistance from the PRC to the post-coup government in Fiji then they ignore the fact that most of this support was agreed between 2001 and 2006, i.e. before the military takeover of December 2006. Putting too much emphasis on the Fiji-PRC relationship also ignores that 'Look North' actually turned out to looking anywhere in the Global South. It also is too simplistic to assume that China, India and others just took advantage of Fijis international isolation. One cannot discount Fijis successful attempt to politically diversify showing elements of Fiji coming to age trying to soften the grip of old colonial friends, who rarely have been unselfish in their conduct with Fiji and other PICs. The diversification of political alliances started when old friends, the USA, but also Australia and New Zealand, showed that their interest in meaningful engagement with the region was declining. The attempt to recertify this under the first tenure of President Obama, is the response of the strengthening of PRC's influence among the PICs. This was not related to coups in Fiji or other political events originating from PICs. The decline in political interest, which led to a perception of neglect on side of the PICs has much to do with the end of the Cold War and other major threats perceived by global (USA) and regional (Australia) powers. This created a vacuum of power urging PICs to reflect from whom to receive support, when support from old friends was becoming unsure, unpredictable, insufficient and/ or attached to political conditions. 'Look North' cannot be explained from a neorealist perception of the international system, but Fiji's own reflexivity aimed to change its IR, aim to create something new as the old structure was perceived as becoming unreliable.

Not much after 2000, under the Qarase Government, 'Look North' was drafted to diversify IR for the sake of greater independence. The assumption-expressed by manythat Fiji's 'Look North' policy has been the result of political isolation after the coup of 2006 is only one picture of a rather complex mosaic. Indeed, after the coup of 2006 it first became a necessity for the military-backed government to fight international isolation. Once internal power was stabilized the government, however, started a rather successful endeavour to get international acceptance and even recognition. This successful 
endeavour on the international scene further stabilizes internal power after the elections of 2014.

\section{India's "Look East" policy and its extended neighbourhood}

The closer cooperation between Fiji and India can hardly be explained alone from motivations and intentions of Fijian Governments. When the Qarase Government was under the influence of ultra-nationalist coalition partners, which strongly pursued pro-iTaukei and anti-Indian politics an all-time political low should have been the "rational" outcome following prevailing political conventions. But IR between the two states developed entirely differently. Even when Indian governments rarely intervened directly politically when rights and conditions of people of Indian origin in Fiji deteriorated, the support Fiji governments received from their Indian counterparts surprises at first sight. To explain this contradiction one has to include motivations and interests followed by Indian governments independent of political events in Fiji.

Increasing Indian outward orientation of the 1980s and early 1990s ended a period in which India was economically and politically inward looking isolating itself economically (import substitution) and politically. Such isolationism started after the first SinoIndian War of 1962 when India withdraw from Nehru's leading role in the Non-aligned Movement (Guha 2011). Economic crises of the 1980s and early 1990s and subsequent economic reforms made the country, among many other things, also discover her diaspora as economic resource (Pande 2011). Special legislation for Non-Resident Indians (NRI) and People of Indian Origin (PIO) tried to tap these resources.

The aftermath of Soviet occupation of Afghanistan and the second oil crisis (1979) had devastating impacts on India's balance of payments. The country's policy of import substitution turned out to be very expensive, made Indian companies technologically outdated and overaged as international competition was kept away. After a severe economic and political crisis in 1990-1991 structural adjustment paved the way to economic success (Weber 1995, 2011, 2012).

Since the end of the twentieth century India has become a global economic powerhouse, much more export orientated than during the decades of import substitution policies. A country that today is described as Asian Elephant competes for economic superiority in Asia (and beyond) with Asian Tigers, but more importantly with the People's Republic of China (PRC), the Asian Dragon.

Even before Fijian politicians started to 'Look North' to foster new and strengthen secondary foreign relations Indian politicians had started to talk of an extended neighbourhood (Chakravarty 2014) and a 'Look East' policy (Mehrotra 2012) to underline India's economic and political aspirations of becoming the dominant Asian power. In the meanwhile Prime Minister Modi has added an action-oriented strategy to his outside oriented policy. In addition to 'Look East' he now also wants to 'Act East', which finds its expression in the third ASEAN-India Plan of Action for the period 2016-2021 (Ganapathi 2015).

To intensify contacts with an ultra-nationalist government in Fiji seems to fit little in such aspiration and strategy: although the biggest and most diverse economy in the Pacific islands region Fiji is miniscule in almost every comparison to India, its economic strengths (and needs), its political and military aspirations. India's willingness to engage 
with Fiji in a meaningful way has little to do with Fiji's economic or political importance for the Asian giant, at least not directly and at least not at first sight. Of course-it is important to keep this in mind-Fiji or the Pacific Islands region does not top the list of priorities in India's IR (Kumar 2014; Yadav 2014).

Like Fijian politicians were looking for political diversification already before the coup of 2006 their Indian counterparts had started with their effort to look beyond the South Asian region a few years earlier. Economic success taking shape from the very end of the twentieth century strengthened India's leadership aspirations beyond South Asia. India became a Summit-level Dialogue Partner of ASEAN in 2002 (Gupta 2013) and strengthened also her bilateral economic and political relations with many ASEAN countries.

Phase-II of India's 'Look East' policy brought closer engagement with Japan, China and the Koreas. In this phase the Southern Pacific attracted India's interest as well. Australia and New Zealand and the PICs became part of India's extended neighbourhood. India's political aspirations, however, go far beyond the Asia-Pacific region.

Becoming a permanent member of the United Nations Security Council (UNSC) should underline the global importance the country has gained. As member of the G4 group (Brazil, Germany, India, and Japan) India hopes for a reformation of the United Nations. Once such reform is completed the G4 countries still require support of $2 / 3$ of the members of the United Nations General Assembly (UNGA) as well as all five present permanent members of the UNSC before they can receive a permanent seat. For long it looked as if India had four of the five permanent members behind its aspiration (USA, Russia, France, and U.K.). Only PRC's support was unsure for long. In 2011 newspapers reported that China is now "ready to support Indian bid for UNSC" (The Hindu 16.7.2011), but apparently only under the condition that India does not support Japan's effort to also become a permanent member of the UNSC (The Hindu 17.7.2011). Fiji's support for India is not entirely new. Already in 2005 the Fiji Government expressed support for permanents seats for India and Japan (Fijilive 5.5.2005). A day after the second Forum on India-Pacific Islands Cooperation (FIPIC, see below) the Indian Government announced that there is widespread support of PICs for India's candidature in the UNSC (The Hindu 21.08.2015). To gather all PICs means 14 votes in the UNGA, which are more than $7 \%$ of the assembly.

\section{India, Fiji and the rest of PICs}

India's cooperation in the Pacific islands region has not been restricted to Fiji. India used Fiji as an entry point to the Pacific islands region. In November 2014 Prime Minister Modi inaugurated the first Forum on India-Pacific Islands Cooperation (FIPIC) in Suva. He met heads of states/governments from all 14 PICs. It was agreed to conduct the FIPIC on regular basis (Times of India 20.11.2014).

India's economic motives to engage in the Pacific island region are not different to those of other countries including the USA, Australia and New Zealand, and China. Economic expansion since the mid-1990s has led to an enormous resource hunger in India. Economic expansion and outward looking economic policies of the 1990s led to a staggering increase in India's consumption of fossil fuels. This was affecting the country's trade balance severely. India's oil import bill increased from US\$180 million in 1970 to US\$6.7 billion in 1980 . The quantity of oil imported in this period did not even 
double. 'Energy diplomacy' became an even more urgent need once economic growth rates picked up in the late 1990s and could be sustained well into the twentyfirst century. In 2013-2014 India's bill for oil imports had increased to USD165 billion, 37\% of all imports (GOI 2014-2015). India does not differ from other emerging powers such as China, Brazil and Russia what resource hunger is concerned. Foreign policies are considerably influenced by the need to secure energy supply (Zhao 2013).

Political expansion to outside South Asia includes considerations to secure resources India urgently needs for its economic expansion. PICs are part of such concerns. Terrestrial mineral resources are mainly available in Melanesian countries (Papua New Guinea [PNG], Solomon Islands, Vanuatu and Fiji). Seabed minerals have been found in the EEZs of the Cook Islands, Kiribati, Marshall Islands, and Tuvalu (manganese, cobalt and other minerals), PNG and Fiji (polymetallic sulphides), and Pitcairn (diamonds). Also other PICs most likely have considerable mineral resources in their EEZs. Exploring these resources has just begun and substantial investment is required to take up deep-sea mining (Powles 2007). Small PICs need cooperation of bigger countries and able investors to benefit from these resources. Fiji authorities are eager to find investors in the mining sector and hope to make mining the country's number one export earner (Brant 2013). Also PNG has considerable fossil fuel resources, which are exploited since a few years, mainly exported to Japan, China and South Korea. Low oil prices since 2014 have dropped PNG's export income from fossil fuels a lot and caused a liquidity crisis. In the medium to long term, however, it is expected that prices will increase again when fossil fuels become scarcer. Also Timor Lesté has meaningful fossil fuel resources. More than $90 \%$ of government revenue is funded from oil exports, making Timor Leste the world's most dependent countries on oil exports (Sýkora 2013). Already in the early 1990s the potential of fossil fuel resources in Fiji has been discussed, but so far there was no successful exploration. To date no Indian companies have been involved in mining activities in PNG, Timor Lesté or Fiji. There are also no examples in other PICs, where Indian companies or Indian aid directly link to resource exploitation.

During the second FIPIC from August 19 to 21, 2015 in Jaipur, India, Prime Minister "Modi expressed optimism [...] to strengthen India's bonds with the 14 resource-rich nations" (Times of India 20.8.2015). On the agenda of the Forum, where heads of all 14 PICs participated, were deeper cooperation with the PICs in the fields of oil and natural gas, mining, IT, health care, fishing and marine research. To strengthen marine research Prime Minister Modi announced India plans to "establish an Institute for Sustainable Coastal and Ocean Research in the region and a network of marine biology research stations in various island nations" (Times of India 22.08.2015). Modi also offered the PICs help with hydrography and coastal surveillance through the Indian Navy. This should help PICs to get "a better understanding of their maritime zone and strengthen security of their EEZs" (Times of India 22.08.2015). Through such cooperation it becomes easier for India to send naval vessels to the Pacific Ocean exploring rather unfamiliar marine terrain. Announced was also cooperation in the field of remote sensing and space exploration, providing assets and technology for the inventory of land and water resources. Modi announced a plan to install a space and satellite monitoring station in Fiji, "which will help India track its satellites independently over the Pacific" (Times of India 22.08.2015). Such cooperation can open India a door to become able to conduct 
surveillance activities from Pacific islands close to the equator. China had such station in Kiribati before the country started diplomatic relations with the Republic of China (ROC, Taiwan). The last two aspects strengthens India's military/naval/surveillance capacities and capabilities in the Pacific Oceans.

To intensify contacts a FIPIC trade office was opened in New Delhi. Citizens of PICs now can travel visa free to India and the annual grant-in-aid to each PIC was increased from USD125,000 to USD200,000 (Times of India 21.8.2015).

India also became a partner in PICs' attempt to fight climate change. The Indian Government promised technical and financial support to strengthen resilience and adaptive capacities, and also political patronage, such as backing of PICs' positions at the COP21 climate change talks held in November 2015 in Paris (Times of India 17.8.2015).

In the Pacific Islands differences in the perception of climate change challenges are well observed. In June 2014 Fiji's Prime Minister Bainimarama criticized the Australian Government "of abandoning Pacific island nations which 'sink below the waves' instead of tackling climate change" (Radio Australia 19.06.2014). Later he accused Australia and New Zealand to "side with what I call the coalition of the selfish, those industrialised nations which are putting the welfare of their carbon-polluting industries and their workers before our welfare and survival as Pacific islanders" (Fijilive 6.05.2015). With such harsh criticism of climate change denial the Fiji Government received much sympathy not only among other PICs, but from many developing countries, which perceive climate change politics as neo-colonial injustice.

The issues are not on climate change alone; they are meant as strong blow against Australia. Australia was the driving force behind Fiji's expulsion from the Pacific Island Forum (PIF) in May 2009. It took Fiji much effort to fend off efforts initiated by Australia and New Zealand to have the involvement of Fiji's military in peace-keeping efforts reconsidered by the UN. From a "rational" perspective a military, which just plotted a coup against its own government should not watch over peace, human rights compliance and other values in foreign countries. Australia and New Zealand, however, were unsuccessful. Fiji's international standing, its networks in those UN bodies that are concerned with peace-keeping operations found more support, also from China and Russia in the UNSC, and India. After elections were held in 2014 Australia was eager to get back to the old structure as soon as possible. This included Fijis return to the PIF, the Pacific islands political organization, often dominated by Australian interests. In October 2014, when Fiji's suspension from the PIF was lifted, Prime Minister Bainimarama announced that Fiji has set conditions for its return to the PIF. "Fiji is not going back to PIF till some changes and reforms are made in the organisation; for example Australia and New Zealand to move out of PIF" (Fiji Sun 25.10.2014). Already in 2013-in response to Fiji's exclusion from the PIF-Fiji had inaugurated the Pacific Islands Development Forum (PIDF). High profile conferences of the PIDF were held in 2014 and 2015, with intensive media coverage and each time with wide international political representation, especially from countries of the Global South. In 2014 the PIDF established its headquarters in Suva, not far from the PIF headquarters. 


\section{Results and discussion}

The Government of Fiji emerged as political winner from the international repercussion the coup of 2006 had created. The military-backed government was politically isolated, expelled from important political bodies, development assistance was frozen and travel sanctions for government officials and military personnel announced. The analysis of Fiji's IR after the coups of 2000 and 2006, however, demonstrates also much latitude for agency suggesting much scope the Fiji Governments possessed to design foreign policies. The Government was not just driven by external structures with little alternatives to pursue. Still agency was restricted by various constraints, especially the severe economic implications political isolation threatened to incur. Searching new political partners, which started as necessity turned into remarkable political success. Long before the country found back to democracy in September 2014 it was able to extend political relations with a big number of countries and was also successful in fostering multilateral political relations. This not only raised self-esteem, but had also its economic advantages. Apart from trying to intensify its relations with the PRC Fiji successfully approached many other countries for closer collaboration. The paper uncovered much evidence for Fiji's agency and also revealed reasons why the small island country started to modify its IR. On the finer details how this happened, however, could not be elaborated. The effort to deconstruct communications that refer to major activities is surely worth doing.

The analysis of Fijis IR shows that neorealist paradigms play a role before 2000. Fiji then was a small capitalist power in an international system dominated by the USA as global and Australia as regional power. The end of the Cold War is lesser a turning point than the events of September 11th, 2001, which temporarily diverted US attention from the Pacific Ocean to other parts of the world, in particular the Middle East and Afghanistan. Starting with the Qarase Government Fijian politics actively sought to change the international system it operates in. Fiji's diversification of IR has a distinct South-South cooperation emphasis. Whether this new orientation remains a 9 days wonder born out of political necessity or will continue to play an important role in Fiji's long-term IR seems to be apparent: Fiji would sacrifice much of its greater political independence if it would return to its system of IR that existed before 2000. Fiji's IR have some impacts on the domestic affairs of the country. Reality differs from assumptions of some approaches that internal structures and events do not inform IR. Displaying international successes, usually with intensive media coverage, serves to create the perception of international acceptance and professionalism. A reality is constructed in which Fiji's Government advocates the country's and the entire Pacific Islands region's interests on international levels. With the diversification of IR closer relations to India and the PRC possibly lead to a stronger identification of Fijians of Indian and Chinese with the ruling party. Such considerations are particular important as the major political party supported by Fijians with Indian ancestry, the Fiji Labour Party, experienced a fiasco in the 2014 elections. 2018 most likely will have a critical election, where a re-orientation of party preferences across greater parts of the electorate is expected. Still it is likely that aspects of IR play a much smaller role in forming people's electoral preferences than internal issues such as rising cost of living and unemployment do. 
Fiji's international success, also its closer cooperation with India, enhances international importance and weight of PICs, especially in issues that concern SIDS in particular, most of all climate change, disaster risk reduction and their connection to human security. While old issues of IR expressed in idealist and realist paradigms centre on issues around war and peace Fiji's IR in the twentyfirst century articulate new issues, such as climate change and disaster risks, issues that in domestic politics are increasingly considered important and also internationally respectable.

\section{Conclusion}

Violent interruption of political processes and institutions through four coups in Fiji were trying times testing traditional political alliances and friendships. After each coup Fiji's political friends and close allies used "soft" pressures trying to bring the country back to democratic principles of governance. This also happened after the coups of 2000 and 2006. After the 2006 coup the military backed government, however, took a much more decisive approach than in earlier situations to diversify political alliances more deliberately and goal-oriented. To look for new friends and to intensify relations with secondary friends, especially amongst other developing countries became the order of the day, not only to overcome isolation, but to present Fiji as a successful actor in international affairs, considering its small size. Fiji was rather successful in this attempt and there are no sign that political diversifications will be given up any time soon to return to a less complex IR regime like it existed prior to 2000 .

What Fiji's relationship with India is concerned there are no signs that the strong and cordial ties that had grown after 2000 are weakening. Turning to a major question of the research it is argued that Fiji's intensified relationships to new and erstwhile secondary friends are more than a mayfly. Fiji's international isolation has been overcome since long and the Indo-Fiji relationship is progressing well. Although Australia, New Zealand, the European Union and other old friends have found back into the circle of Fijis friends India, China and many other remained there, enhancing the diversity of Fiji's IR making all relations more stable and predictable.

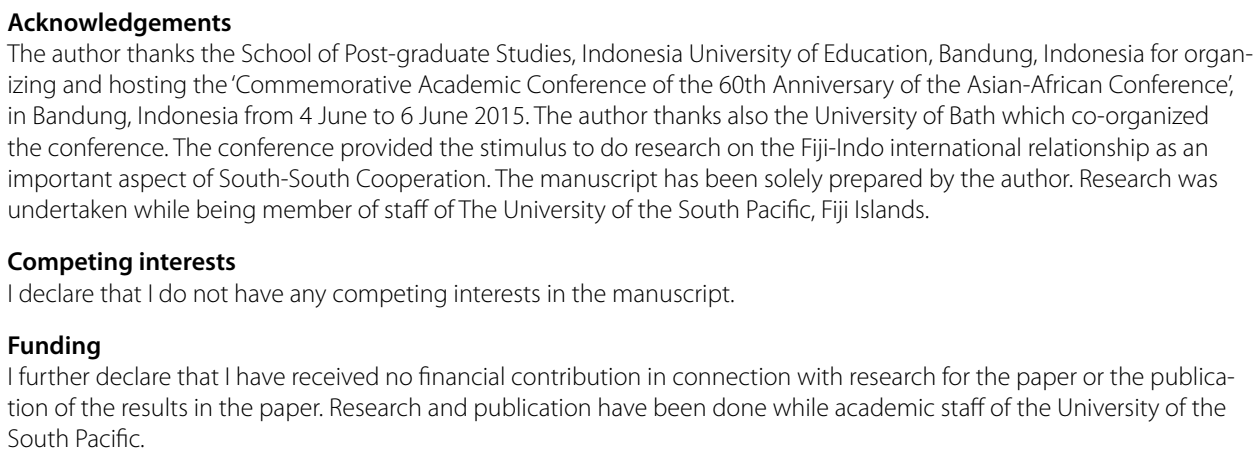
izing and hosting the 'Commemorative Academic Conference of the 60th Anniversary of the Asian-African Conference', in Bandung, Indonesia from 4 June to 6 June 2015. The author thanks also the University of Bath which co-organized the conference. The conference provided the stimulus to do research on the Fiji-Indo international relationship as an important aspect of South-South Cooperation. The manuscript has been solely prepared by the author. Research was undertaken while being member of staff of The University of the South Pacific, Fiji Islands.

Competing interests

I declare that I do not have any competing interests in the manuscript.

Funding

I further declare that I have received no financial contribution in connection with research for the paper or the publication of the results in the paper. Research and publication have been done while academic staff of the University of the South Pacific.

Received: 8 July 2016 Accepted: 14 March 2017

Published online: 17 March 2017 


\section{References}

Adler, Emanuel. 2013. Constructivism in international relations: Sources, contributions, and debates. In Handbook of international relations, ed. Walter Carlsnaes, Thomas Risse, and Beth A. Simmons, 112-144. London and Thousand Oaks: Sage.

Archer, S. 2010. Remedial agents: Missionary physicians and the depopulation of Hawai'i. Pacific Historical Review 79: 513-544. doi:10.1525/phr.2010.79.4.513.

Bainimarama, Josia Voreque. 2011. Speech before the UN General Assembly. Accessed June 13, 2015 http://gadebate. un.org/sites/default/files/gastatements/66/FJ_en.pdf.

Baker Fox, Annette 1959. The power of small states. Diplomacy in World War II. Chicago: University of Chicago; Toronto: University of Toronto Press.

Behnke, A. 2001. Grand theory in the age of its impossibility. Contemplations on Alexander Wendt. Cooperation and Conflict 36: 121-134. doi:10.1177/00108360121962326.

Bertram, Geoffrey, and Ray F. Watters. 1986. The MIRAB process: Some earlier analysis and context. Pacific Viewpoint 27 (47-5): 7.

Brant, P. 2013. Chinese aid in the South Pacific: Linked to resources? Asian Studies Review 37: 158-177. doi:10.1080/10357 823.2013.767311.

Briguglio, L. 1995. Small Island developing states and their economic vulnerabilities. World Development 23: 1615-1632. doi:10.1016/0305-750x(95)00065-k

Copeland, D.C. 2000. The constructivist challenge to structural realism. International Security 25: 187-212. doi:10.1162/016228800560499.

Chakravarty, Pinak Ranjan. 2014. India's foreign policy in the neighbourhood. Indian Foreign Affairs Journal 9: 142-157.

Clarke, Colin, and Tony Payne (eds.). 1987. Politics, security and development in small states. London: Allen and Unwin.

Crocombe, Ronald G. 2007. Asia in the Pacific islands: replacing the West. Suva: IPS Publications.

Dommen, Edward, and Philippe Hein (eds.). 1985. States, microstates, and islands. London: Routledge.

Drulák, Petr. (2006). Reflexivity and structural change. In Constructivism and International Relations. Alexander Wendt and his critics, eds, Stefano Guzzini and Anna Leander, 138-157. Oxon and New York: Routledge.

Ellis, F. 1988. Small-farm sugar production in Fiji: Employment and distribution aspects. IDS Bulletin 19:47-53. doi:10.1111/j.1759-5436.1988.mp19002007.x.

Fraenkel, Jon, Stewart Firth, and Brij V. Lal (eds.). 2009. The 2006 military takeover in Fiji: A coup to end all coups?. Canberra: ANU E Press.

Fraenkel, J. 2004. The coming anarchy in Oceania? A critique of the "Africanisation of the South Pacific" thesis. Journal of Commonwealth \& Comparative Politics 42: 1-34. doi:10.1080/14662040408565567.

Friedman, Gil, and Harvey Starr. 1997. Agency, structure and international politics: From ontology to empirical inquiry. London and New York: Routledge.

Ganapathi, M. 2015. 'Look East-Act East' Dimension of India's Foreign Policy. Indian Foreign Affairs Journal 10 (1): 63.

Government of India (GOI). Economic Survey 2014-15. New Delhi.

Grote, Jenny. 2010. The changing tides of small island states discourse-A historical overview of the appearance of small island states in the international arena. Verfassung und Recht in Übersee 43: 164-191.

Guha, Ramachandra. 2011. An Asian clash of civilisations? Revisiting the Sino-Indian conflict of 1962. Economic \& Political Weekly 46 (44/45): 51-61.

Gupta, G.S. 2013. India's foreign policy. Mongolian Journal of International Affairs 12: 8-20. doi:10.5564/mjia.v0i12.90.

Haftendorn, Helga. 1990. Zur Theorie aussenpolitischer Entscheidungsprozesse. In Theorien der Internationalen Beziehungen-Bestandsaufnahme und Forschungsperspektiven, ed. Volker Rittberger, 401-423. Opladen: Westdeutscher.

Hambro, C. 1936. The role of the smaller powers in international affairs to-day. International Affairs 15: 167-182. doi: 10.2307/2601738.

Hambro, E. 1943. Small states and a new league-From the viewpoint of Norway. The American Political Science Review 37: 903-909. doi:10.2307/1949105.

Herre, Paul. 1937. Die kleinen Staaten Europas und die Entstehung des Weltkrieges. Muenchen: C.H. Beck.

Henderson, John, Benjamin Reilly, and Nathaniel Peffer. 2003. Dragon in paradise: China's rising star in Oceania. The National Interest 72: 94-105.

Igler, D. 2015. Hardly Pacific: Violence and death in the Great Ocean. Pacific Historical Review 84: 1-18. doi:10.1525/ phr.2015.84.1.1.

Indian Ministry of External Affairs. 2016. Population of Overseas Indians as of December 2016. Accessed March 5, 2017 http://mea.gov.in/images/attach/NRIs-and-PIOs_1.pdf.

Kaldor, Mary. 1999. New and old wars: Organized violence in a global era. Cambridge: Wiley.

Karlsson-Vinkhuyzen, S.I. 2012. From Rio to Rio via Johannesburg: Integrating institutions across governance levels in sustainable development deliberations. Natural Resources Forum 36: 3-15. doi:10.1111/j.1477-8947.2011.01435.x

Kelman, Ian. 2006. Island security and disaster diplomacy in the context of climate change. Les Cahiers de la Sécurité 63: 61-94.

Keohane, R.O. 1969. Lilliputians' dilemmas: Small states in international politics alliances and the Third World. International Organization 23: 291-310. doi:10.1017/s002081830003160x.

Keohane, R.O. 1971. The big influence of small allies. Foreign Policy 2: 161-182. doi:10.2307/1147864.

Kaplan, Robert. 1994. The coming anarchy. The Atlantic Monthly, February, 44-76.

Kumar, A.Vinod. 2014. 'Indo-Pacific': India will be a fringe player. Indian Foreign Affairs Journal 9: 136-141.

Lal, Brij V. 2004. Girmitiyas the origins of the Fiji Indians. Lautoka: Fiji Institute of Applied Studies.

Lambert, Sylvester Maxwell. 1934. The depopulation of Pacific races, 23. Bernice P: Bishop Museum Special Publication.

Liska, George. 1968. Alliances and the third world: Studies in International Affairs No. 5. Baltimore, Md: Johns Hopkins Press.

List, Martin. 2008. Historisch-soziologische Perspektive in der Analyse internationaler Politik. In Politikwissenschaftliche

Perspektiven, ed. Stephan Bröchler, and Hans-Joachim Lauth, 143-166. Wiesbaden: VS.

Maclellan, N. 2005. The nuclear age in the Pacific islands. The Contemporary Pacific 17: 363-372. doi:10.1353/cp.2005.0062.

McVadon, Eric. 2007. China and the United States on the high seas. China Security 3: 3-28. 
Mehrotra, Lakhan. 2012. India's look east policy: Its origin and development. Indian Foreign Affairs Journal 7: 75-85. Ministry of Overseas Indian Affairs. 2015. Assessed June 2nd, 2016 http://moia.gov.in/services.aspx?ID1=300\&id=m8\&id $\mathrm{p}=59$ \& mainid $=23$.

Morgenthau, Hans J. 1948. Politics among nations: The struggle for power and peace. New York: Knopf.

Moynagh, M. 1978. Land tenure in Fiji's sugar cane districts since the 1920s. The Journal of Pacific History 13: 53-73. doi:10.1080/00223347808572338.

Naidu, Vijay. 1980. The violence of indenture in Fiji. Suva: World University Service.

Onuf, Nicholas Greenwood. 1989. World of our making: Rules and rule in social theory and International Relations. Columbia, SC: University of South Carolina Press.

O'rourke, T.J., J.A. Nelson, and J.G. Volan. 2012. Reagan test site distributed operations. Lincoln Laboratory Journal 19 : $77-88$.

Pande, Amba. 2011. India and its diaspora in Fiji. Diaspora Studies 4: 125-138.

Poirine, Bernad. 1998. Should we hate or love MIRAB? The Contemporary Pacific 10: 65-106.

Power, P.F. 1986. The South Pacific Nuclear-Weapon-Free Zone. Pacific Affairs 59: 455-475. doi:10.2307/2758329.

Powles, Michael. 2007. China looks to the Pacific. CSCSD Occasional Paper 1: 50.

Rappard, W.E. 1934. Small states in the League of Nations. Political Science Quarterly 49: 544-575. doi:10.2307/2143465.

Reilly, B. 2000. The Africanisation of the South Pacific. Australian Journal of International Affairs 54: 261-268. doi:10.1080/00049910020012552.

Rivers, William Halse. 1922. Essays on the depopulation of Melanesia. London: Cambridge University Press.

Rodriguez, Junius P. 2011. Slavery in the modern world: a history of political, social, and economic Oppression, vol. 2. ABCCLIO, LLC: Santa Barbara.

Rothstein, R.L. 1966. Alignment, nonalignment, and small powers: 1945-1965. International Organization 20: 397-418 doi:10.1017/S0020818300012856.

Rothstein, Robert L. 1968. Alliances and small powers. New York and London: Columbia University Press.

Serrano, Susan. 2014. The human costs of "Free Association": Socio-cultural narratives and the legal battle for Micronesian health in Hawai'i. The John Marshall Law Review 47: 12

Skagestad, G. 1974. Small states in international politics: A Polar-political perspective. Cooperation and Conflict 9 (2-3) 185-193. doi:10.1177/001083677400900116.

Stevens, Eric V. 1950. Blackbirding: a brief history of the South Sea Islands labour traffic and the vessels engaged in it. Journal of the Royal Historical Society of Queensland 4: 361-403.

Sutton, P., and A. Payne. 1993. Lilliput under threat: the security problems of small island and enclave developing states. Political Studies 41: 579-593. doi:10.1111/j.1467-9248.1993.tb01657.x

Sýkora, J. 2013. Oil in Timor-Leste: A ticket to prosperity? Acta Oeconomica Pragensia 21:68-85. doi:10.18267/j.aop.405.

Teschke, Benno. 2003. The myth of 1648: Class, geopolitics and the making of modern International Relations. London/New York: Verso.

Thakur, R. 1985. India and overseas Indians: The case of Fiji. Asian Survey 25: 356-370. doi:10.2307/2644124.

Vellut, J.-L. 1967. Smaller states and the problem of war and peace: Some consequences of the emergence of smaller states in Africa. Journal of Peace Research 4: 252-269. doi:10.1177/002234336700400303.

Waltz, Kenneth N. 1979. Theory of international politics. Reading, MA: Addison-Wesley.

Weber, Cynthia. 2010. International relations theory — A critical introduction, 3rd ed. London and New York: Routledge.

Weber, Eberhard. 1995. Globalisierung und Politische Ökonomie der Armut in Indien, Madras/Limbach.

Weber, E. 2007. Gewalt und Staatsversagen in Fidschi. Zeitschrift fuer Wirtschaftsgeographie 51 (3-4): 206-220. doi:10.1515/zfw.2007.0016.

Weber, Eberhard. 2011. Gandhi, Galtung und Globalisierung -Ländliche Entwicklung in Indien 1947-2011. Göttingen: Cuvillier.

Weber, E. 2012. Economic reform, social development and conflict in India. Regional Science Policy \& Practice 4: 207-230. doi:10.1111/j.1757-7802.2012.01069.x.

Weber, E. 2014. Environmental change and (im)mobility in the South. In A new perspective on human mobility in the South, ed. Rudolf Anich, Jonathan Crush, Susanne Melde, and John O. Oucho, 119-148. Dordrecht: Springer. doi:10.1007/978-94-017-9023-9_6.

Wendt, A. 1987. The agent-structure problem in International Relations theory. International Organization 41: 335-370. doi:10.1017/S002081830002751x.

Wendt, A. 1992. Anarchy is what states make of it: the social construction of power politics. International Organization 46: 391-425. doi:10.1017/S0020818300027764.

Wendt, Alexander. 1999. Social theory of international politics. Cambridge: Cambridge University Press.

Yadav, R.S. 2014. 'Indo-Pacific': Likely to be peripheral for India. Indian Foreign Affairs Journal 9: 125-130.

Wendt, A. 1995. Constructing international politics. International Security 20 (1): 71-81. doi:10.2307/2539217.

Wilcox, W.A. 1967. The influence of small states in a changing world. The Annals of the American Academy of Political and Social Science 372: 80-92. doi:10.1177/000271626737200109.

Wolfers, A. 1945. The role of the small states in the enforcement of international peace. Proceedings of the Academy of Political Science 21: 24-31. doi:10.2307/1173055.

Zehfuss, M. 2013. Critical Theory, Poststructuralism, and Postcolonialism. In Handbook of international relations, ed. Walter Carlsnaes, Thomas Risse, and Beth A. Simmons, 145-169. London and Thousand Oaks: Sage. doi:10.4135/9781446247587.n6.

Zhang, Y. 2007. China and the emerging regional order in the South Pacific. Australian Journal of International Affairs 61 (3): 367-381. doi:10.1080/10357710701531537.

Zhao, Hong. 2013. China and India: The quest for energy resources in the 21st Century. Abingdon and New York: Routledge. 